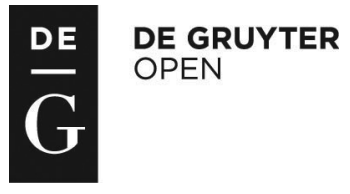

\title{
FACTORS DETERMINING THE SUSCEPTIBILITY OF COWS TO MASTITIS AND LOSSES INCURRED BY PRODUCERS DUE TO THE DISEASE - A REVIEW*
}

\author{
Zygmunt Litwińczuk ${ }^{1 *}$, Jolanta Król², Aneta Brodziak ${ }^{1}$ \\ ${ }^{1}$ Department of Breeding and Conservation of Cattle Genetic Resources, \\ ${ }^{2}$ Department of Commodity Science and Processing of Raw Animal Materials, \\ University of Life Sciences in Lublin, Akademicka 13, 20-950 Lublin, Poland \\ •Corresponding author: zygmunt.litwinczuk@up.lublin.pl
}

\begin{abstract}
The aim of the paper was to discuss the factors determining the susceptibility of cows to mastitis, the most important for breeders, including losses incurred by milk producers due to the disease. Inflammations of mammary gland are common and the most awkward problem which dairy farmers face around the world. In the case of clinical udder inflammation, it is estimated that the cost of mastitis is about $200 €$ per cow with fluctuations from 100 even up to $1000 €$. Resistance, i.e. the susceptibility of cows to mastitis, is conditioned genetically. The possibility of BoLA and lactoferrin gene polymorphism, using in the selection cows resistant to mastitis, is indicated. Bacteria inhabiting the mammary gland, and the living environment of animals are primarily the main etiological factor. Moreover, many authors indicate the differences between breeds of cows in resistance to mastitis. High-productive breeds are generally more susceptible to the udder inflammation, in comparison to the local breeds. The greatest reduction in milk yield is observed in the case of these breeds, and especially in Holstein-Friesian breed, in which the decline of daily yield at somatic cell count (SCC) amounting above 500,000 per $\mathrm{ml}$ of milk can reach $25 \%$. The probability of mastitis occurrence increases with an age of cows and following lactation, and dry period is a time of increased risk. Higher incidence of inflammation is also associated with abnormalities in the construction of the udder (unevenly developed quarters, too long or too short teats). In recent years, a possible relationship between feeding system of cows with their resistance to udder infections has been reported. It is emphasized that a deficiency of selenium and vitamins $A$ and $E$ in the ration may contribute to the increase in the number of mastitis incidences. There are, however, unclear opinions of various authors on the effect of automatic milking system on udder health.
\end{abstract}

Key words: udder inflammations, cow breed, hygiene and system of milking, losses of milk producers

Bovine mastitis is a complex, multi-etiological disease which is closely linked to the production system and environment in which cows are kept. During inflam-

*Work financed from statutory activity. 
mation, pathological changes of a physical, chemical and bacteriological nature take place in the gland tissue of the udder, as well as in the milk obtained (Hagnestam et al., 2007). The milk yield of the cows decreases as well, and numerous studies (Khan and Khan, 2006; Litwińczuk et al., 2011) have shown that highly productive breeds are more susceptible to inflammation, so that losses in milk production are greater. The reduced synthetic activity of the infected mammary gland is also manifested in changes in the content of individual milk components and their relative proportions, leading to a reduction in the nutritional value of the milk and its suitability for processing. Mastitis induces changes in protein distribution (the percentage of whey proteins increases and that of casein decreases), a reduction in fat and lactose content, and changes in the concentration of mineral nutrients, mainly a decrease in calcium (Barłowska et al., 2009; Jones and Bailey, 2009; Król et al., 2010; Litwińczuk et al., 2011; Olechnowicz and Jaśkowski, 2012). The scope of these changes is varied and depends on the advancement of the infection (Litwińczuk et al., 2011; Pyörälä, 2003). Oviedo-Boyso et al. (2007) point out that mastitis is a multi-factor disease dependent on exposure of the udder to pathogens, the effectiveness of its defence mechanisms, the presence of risk factors in the natural environment, and the interaction between these factors. The aim of the paper was to discuss the factors determining the susceptibility of cows to mastitis, the most important for breeders, including losses incurred by milk producers due to the disease.

\section{Genetic aspects of mastitis}

Susceptibility or resistance to mastitis in dairy cows has a genetic basis. Selection for increased milk yield has been shown to have a detrimental effect on the health condition of the mammary gland (Rupp and Boichard, 2003). The disease is thus a problem mainly in high-production herds raised in intensive farming conditions. However, direct selection for resistance to mastitis is uncommon due to its low heritability (Table 1). The results of numerous studies (Norberg et al., 2009; Penasa et al., 2010) indicate that values for the heritability coefficient for somatic cell count (SCC) or the natural $\log$ of the SCC (SCS) do not exceed 0.20 . The heritability coefficient for mastitis is even lower (0.01-0.17) (Bloemhof et al., 2009; Carlen et al., 2004).

Low values for the heritability coefficient for susceptibility of cows to mastitis do not, however, mean a lack of genetic variability, but environmental factors have a substantial influence on the phenotypic effect.

Table 1. Heritability estimates $\left(\mathrm{h}^{2}\right)$ for somatic cell count (SCC) and mastitis

\begin{tabular}{lll}
\hline \multicolumn{1}{c|}{$\mathrm{h}^{2}$} & \multicolumn{1}{c}{ Parameter } & \multicolumn{1}{c}{ References } \\
\hline $0.11 \pm 0.04$ & SCC & Mrode and Swanson, 1996 \\
$0.096 \pm 0.016$ & SCC & Sender, 2001 \\
$0.07-0.11$ & SCC & Dube et al., 2008 \\
$0.14-0.15$ & SCC & Norberg et al., 2009 \\
$0.07-0.14$ & SCC & Ptak et al., 2009 \\
$0.09-0.18$ & SCC & Rzewuska et al., 2011 \\
ca. 0.04 & mastitis & Mrode and Swanson, 1996 \\
$0.02-0.04$ & clinical mastitis & Rupp and Boichard, 2003 \\
$0.01-0.17$ & mastitis & Carlen et al., 2004; Bloemhof et al., 2009 \\
\hline
\end{tabular}


Recently genetic markers determining the susceptibility of cows to mastitis (MAS - marker-assisted selection) have been sought as well. MAS uses genetic markers to identify specific regions of chromosomes containing genes that influence various quantitative characteristics, called QTL (quantitative trait loci), associated with mammary gland development, the productivity of cows and resistance or susceptibility to mastitis. Thus far a total of 415 quantitative trait loci, including 71 associated with mastitis, have been submitted to databases (Ogorevc et al., 2009). This information is used to assess the genetic value of animals, including selection of individuals that are less susceptible to mastitis. There is a potential for the use of lactoferrin and class II BoLA (bovine leukocyte antigen) genes in selection of mastitis-resistant cows. Lactoferrin, by binding and sequestering iron, exhibits antibacterial properties against Gram-positive and Gram-negative bacteria, including those inducing mastitis (Król et al., 2010; Pawlik et al., 2014). This effect is partly due to the protein's ability to chelate iron $\left(\mathrm{Fe}^{3+}+\right.$ ions), thereby removing it from the growth environment of bacteria. The lactoferrin gene in cattle is located on chromosome 22 and is composed of 17 exons (Arnould et al., 2009). Many authors (Arnould et al., 2009; Ashwell et al., 2004; Pawlik et al., 2014) have demonstrated a relationship between lactoferrin genotype and the percentage content of protein and fat in milk, as well as the somatic cell count (which is an indicator of the health of the udder). According to Sender et al. (2006), the BB lactoferrin genotype is the most favourable in terms of reducing the incidence of mastitis, as the lowest somatic cell count was noted in this group of animals. Unfortunately, it should be emphasized that cows with the BB genotype are infrequent in the cattle population. On the other hand, in a study by Wojdak-Maksymiec et al. (2006) the lowest SCC was noted in cows with the AA genotype. Both studies confirmed that cows with the AB genotype were most susceptible to mastitis. Apart from A and B, other alleles of the lactoferrin gene are also linked to SCC in milk. Kamiński et al. (2006) suggest that the G allele reduces expression of lactoferrin, which is manifested as a lower somatic cell count, while the $\mathrm{C}$ allele increases expression of lactoferrin, thereby enhancing the immune response and increasing the somatic cell count in the milk. In another study, the same authors (Zabolewicz et al., 2012) found that the $\mathrm{C}$ allele occurred significantly more often in cows with a low somatic cell count. A link has also been demonstrated between class II BoLA genes and the occurrence of mastitis in cows, with the BoLA DRB3 gene, located in cattle on chromosome 23, proving the most promising in this respect (Sender et al., 2006; Sharif et al., 2000; Wojdak-Maksymiec et al., 2010). Research (Pashmi et al., 2009; Sender et al., 2006) indicates a significant link between the BoLA DRB3.2*16 allele and the occurrence of udder inflammation. The significantly lowest somatic cell count was noted in the milk of the group of cows that were carriers of this allele. Sender et al. (2006), after analysing the effect of the interaction of lactoferrin and BoLA DRB3 genotypes on SCC, suggest that cows with the BB lactoferrin genotype that are also carriers of the BoLA DRB3*16 allele are most resistant to mastitis.

In some European countries, i.e. Finland, Norway or Sweden, SCC and clinical mastitis have been included in breeding index (Hogeveen, 2005). 


\section{Type of purpose and breed of cows}

Mastitis is a common problem and the most onerous one facing milk producers all over the world. It can appear at any time in any dairy herd, even in the most organized ones, so every herd is potentially at risk (Elbably et al., 2013; Sudhan and Sharma, 2010). It should be emphasized that there are differences between breeds in resistance of cows to mastitis. Rupp and Boichard (2003) report that in French breeds (Montbéliarde and Abondance) and central European breeds (Simmental and Brown Swiss) clinical forms of mastitis are less common, and their milk contains fewer somatic cells than that of Holsteins. This has been confirmed by Gołębiewski and Brzozowski (2007), who found that the Montbéliarde breed is more resistant to mastitis than the Holstein-Friesian breed, as indicated by a $23-38 \%$ lower somatic cell count in the milk.

Highly productive breeds are generally more susceptible to various types of disease, including mastitis (Walsh et al., 2007). According to Compton et al. (2007), the risk of the clinical form of mastitis is greater in Friesian cows than in Jerseys and Ayrshires, and local breeds also show greater resistance to inflammatory states. In a study by Król et al. (2013), irrespective of age and the stage of lactation the milk of cows of local breeds (Polish Red and White-Backed) had a significantly lower somatic cell count than that of Holstein-Friesians. Walsh et al. (2007) analysed somatic cell count in cows of four breeds (Holstein-Friesian, Normande, Norwegian Red and Montbéliarde) and found the lowest values in the milk of the Norwegian Red and Montbéliarde cows. A study by Litwińczuk et al. (2011) evaluating the milk of cows of four breeds - Polish Black-and-White Holstein-Friesian, Polish Red-and-White Holstein-Friesian, Simmental and Jersey - found significant interactions $(\mathrm{P} \leq 0.05)$ between the breed of cow and SCC for BSA content, which according to the authors may suggest varied susceptibility in these breeds to increased somatic cell count. This is also confirmed to some extent by the varied correlation coefficients between SCC and BSA content in the milk ( $\mathrm{r}=0.711$ - Holstein-Friesian; $\mathrm{r}=0.577$ - Simmental and $\mathrm{r}=0.472$ - Jersey). Hence it may be presumed that in Simmental and Jersey cows with increased SCC serum albumin does not pass from the blood to the milk as intensively as in Holstein-Friesians. This would indicate greater resistance of these breeds, i.e. Simmental and Jersey, to mammary gland infections.

The mammary gland in beef cows serves to produce the milk necessary to feed their young. The udder of nursing cows is naturally emptied by the calves several times or even more than a dozen times a day, and as a rule no mechanical damage to the teats or acute infections are observed. For this reason the occurrence of mastitis is not as carefully monitored in beef cow herds. However, research (Lents et al., 2008) shows that the problem of mastitis in beef cows exists and is taking on increasing importance. Waller et al. (2014) showed that both subclinical mastitis and acute inflammatory states are common among beef cows in Sweden, affecting 50\% and $40 \%$ of animals, respectively. The authors indicate Staphylococcus aureus as the main etiological agent responsible for inducing inflammatory states. Paape et al. (2000) detected infections in $66.1 \%$ of cows in $31.7 \%$ of quarters during weaning of calves. Lents et al. (2008) noted considerably fewer infected cows (27\%) in a beef herd. 


\section{Udder structure}

Research conducted in Poland in the 1980s and 1990s (Borkowska and Litwińczuk, 1989; Guliński et al., 1996; Litwińczuk et al., 1990) demonstrated that improvement of domestic Holstein-Friesian cattle led to a more favourable udder structure and greater suitability of cows for mechanical milking. The possibility of improving characteristics of udder structure by means of selection is indicated by the estimated heritability coefficients $\left(\mathrm{h}^{2}\right)$, which according to Guliński et al. (1996) range from 0.19 (teat placement) to 0.39 (central ligament).

Udders with unequally developed quarters are most susceptible to infections. More frequent occurrence of inflammation is also associated with the presence of long teats, which are at greater risk of damage (Awale et al., 2012). Waller et al. (2014) report that cows with a pendulous udder after calving or an udder with long, funnel-shaped teats or inactive quarters are at a high risk of subclinical mastitis. Cows with mastitis have been observed to have smaller teats and shorter teat canals, with a larger teat base and diameter (Hussain et al., 2012). The disease is also linked to the cross-sectional area of the teat canal (Awale et al., 2012; Hussain et al., 2012). The larger the cross-sectional area, the less elastic are the muscles closing it, so that it remains open longer after milking and the susceptibility to infection increases.

\section{Age of cows and stage of lactation}

Both the age of cows and the stage of lactation are important factors associated with the occurrence of mastitis. Elbably et al. (2013) found highly significant $(\mathrm{P}<0.01)$ relationships between occurrence of mastitis and the number and stage of lactation. Van den Borne et al. (2010) evaluated herds of dairy cows in the Netherlands and noted the occurrence of mastitis in $12.8 \%$ of primiparous cows and $27.1 \%$ of multiparous cows. Abrahmsén et al. (2014) diagnosed the subclinical form of mastitis in $79.2 \%$ of primiparous cows and $88.4 \%$ of multiparous cows. Shittu et al. (2012) report a significantly $(\mathrm{P}<0.001)$ lower risk of subclinical mastitis among primiparous cows, which can be linked to the fact that the teat canal in older animals is wider due to frequent milking over several years, or it may permanently remain partly open.

The age of cows may also affect the permeability of the mammary epithelium, which can be linked to damage caused by previous inflammatory states leading to increased permeability even after successful treatment (Król et al., 2013). According to Parker et al. (2007), in heifers with an infected udder before parturition the risk of clinical mastitis after calving is as much as 4 times greater than in uninfected cows. The problem of clinical mastitis in pregnant heifers and primiparous cows during calving time has also been discussed by other authors (Borm et al., 2006; Malinowski and Smulski, 2007).

Mastitis cases are particularly frequent immediately after parturition, in early lactation and during the first 2-3 weeks of the dry period (Sudhan and Sharma, 2010; Tiwari et al., 2013). This is probably due to increasing oxidative stress and lower efficiency of antioxidant defence mechanisms at the start of lactation. Berry and Meaney (2005) state that given data on lactation number and the month of calving, it is possible to predict the probability that clinical mastitis will occur in subsequent 
stages of lactation. Salamończyk and Guliński (2013) point out the effect of prolonged lactation (from day 306 to the end of lactation) on somatic cell count in the milk, i.e. after 305 days SCC increased significantly $(542,000 / \mathrm{ml})$ in comparison with standard lactation $(409,000 / \mathrm{ml})$. However, they found a significant $(\mathrm{P}<0.01)$ negative correlation between daily milk yield during prolonged lactation and somatic cell count $(\mathrm{r}=-0.23)$, which indicates that cows with lower milk yield in prolonged lactation are more susceptible to mastitis.

\section{Milking system and hygiene}

Observing hygiene during milking is particularly important in counteracting and combating infectious mastitis in the herd. Shittu et al. (2012) noted that in cows kept in herds in which milking is conducted in a traditional manner and hand-washing before milking is a frequent practice, the risk of development of subclinical mastitis was lower than in cows in herds in which hand-washing was not observed. Abrahmsén et al. (2014) confirmed a statistical $(\mathrm{P}<0.003)$ relationship between udder hygiene and occurrence of subclinical mastitis. In Holstein-Friesian cows with a good level of udder hygiene 1.63 quarters were affected by inflammation, while in cows whose udders were inadequately cared for (poor hygiene) infections were noted in 2.72 quarters. Of 140 cows with poor udder hygiene as many as $123(87.9 \%)$ were infected with subclinical mastitis. Dohmen et al. (2009) found positive correlations between SCC in the milk of cows milked by robots and cleanliness of the animals' udders and limbs, and one of the causes they suggested was failure to recognize various types of soiling of the udder by the milking device. According to Smith et al. (2002), the prevalence of mastitis in cows is also affected by the frequency of milking. A significantly lower somatic cell count was observed in the milk of cows milked three times than in that of cows milked twice. Studies conducted in Finland (Hovinen et al., 2009) and the Netherlands (Dohmen et al., 2009) show that the introduction of an automatic milking system led to a deterioration of the health condition of the mammary gland. An increase in bulk milk SCC is also caused by failure to separate cows with mastitis (Hovinen et al., 2009). Sudhan and Sharma (2010) and Tiwarii et al. (2013) demonstrated that automatic milking, in comparison with conventional milking, affected the health condition of the mammary gland, increasing the occurrence of inflammation. Voorst van der and Hogeveen (2000), evaluating the effect of automatic milking on farms in the Netherlands, observed an increase in the amount of milk with an elevated total bacterial count, which in their opinion may have resulted from improper milking management. This might seem to be confirmed by a study by Zecconi et al. (2003) which showed that in the case of proper herd management the use of milking robots can even reduce somatic cell count in the milk.

\section{Dry period}

The dry period is considered to be one of the most important periods influencing the health condition of the udder in cows, and is also a time of increased risk of mastitis (Madouasse et al., 2012). During this period dynamic changes take place in the physiological, metabolic and hormonal status of the cow, primarily regeneration of 
the gland tissue of the udder. The optimal length of the dry period for a 305 day lactation period is considered to be 40-60 days. Studies by many authors (Kuhn et al., 2007; Sawa et al., 2015; Węglarzy, 2009) have shown that elimination or shortening of the dry period reduces resistance of the udder to inflammatory states, leading to an increase in somatic cell count in the milk in the subsequent lactation. Kuhn et al. (2007) observed that SCC increased relatively by $10 \%$ over the average when the dry period lasted up to 20 days and by $4.6 \%$ in the case of dry periods lasting 21-30 days. Węglarzy (2009) reports that for Holstein-Friesian cows the dry period should optimally last 60-90 days. In cows dried out for less than 30 days a decrease (on average by $4.82 \%$ ) was noted in the percentage of milk samples with SCC below 400,000/ml. According to Sawa et al. (2015), the optimal dry period for Polish Holstein-Friesians is 61-80 days. Irrespective of the age of the cows, both shortening and prolonging of the dry period increase the risk of clinical changes in the udder, and the percentage of milk samples indicating clinical mastitis increased when the dry period was excessively prolonged ( $>100$ days), particularly in multiparous cows.

In a study analysing 196 cows of the beef breed Angus and Angus $\times$ Hereford crossbreds raised in the USA, Lents et al. (2008) found that treatment of dry cows (following separation from calves) significantly $(\mathrm{P}=0.005)$ reduced the number of infected animals after calving. Administration of antibiotics to dry beef cows reduced the number of udder infections at the next calving, which in turn had a positive effect on weight gains in the calves during rearing. Laven et al. (2014) found no effect of the length of the dry period on the risk of clinical mastitis in dairy cows and no significant interactions in combination with treatment.

\section{Feeding system and season}

Certain studies conducted in recent years (Abrahmsén et al., 2014; Sudhan and Sharma, 2010) indicate a connection between the feeding system for dairy cows and their resistance to udder infections. Abrahmsén et al. (2014) reported that cows that were not pastured were more susceptible to the subclinical stage of mastitis, as among 23 cows in the group analysed inflammatory states were found in as many as 22 (95.7\%). According to Smith et al. (1997), vitamins E and A are particularly significant dietary components, as are $\beta$-carotene, selenium, copper and zinc. Vitamin $\mathrm{E}$ and selenium influence phagocytosis taking place in cells, so that a greater risk of mastitis is observed in cows whose diet is deficient in these components, particularly mastitis induced by Streptococcus spp. Sharma and Maiti (2005) state that the health-promoting effect of vitamin $\mathrm{E}$ and selenium is particularly manifest after calving and in early lactation. According to Sudhan and Sharma (2010), vitamin A and $\beta$-carotene deficiencies also lead to an increase in the number of cases of mastitis observed in cows.

In general, cattle feeding systems closely linked to the season of the year predominate worldwide. Harouna et al. (2009) observed that during the rainy season $55.2 \%$ of cows exhibited symptoms of subclinical mastitis, which was twice as many as during the drier period $-27.1 \%(\mathrm{P}<0.05)$. Tiwarii et al. (2013) also report more frequent occurrence of mastitis in the rainy summer months. 


\section{Losses incurred by milk producers}

Mastitis is one of the most costly diseases in dairy cattle and one of the most difficult to control using veterinary methods. It causes economic losses and poses a serious threat to the stability of dairy cow population size, as apart from sterility and disorders of the limbs (lameness) it is the most frequent cause of culling of cows from the herd and reduces production efficiency (Awale et al., 2012). Huijps et al. (2008) report that mastitis accounts for about $70 \%$ of all economic losses incurred on dairy farms. According to Schroeder (2012), mastitis-related costs incurred by farmers are mainly the result of losses associated with reduced milk production (about 70\%), unsuitability of milk for consumption and processing (13.5\%), limited possibility of restoring the size of the herd $(8.0 \%)$, reduced sales value $(5 \%)$ and treatment costs $(6 \%)$, as well as increased labour expenditures (1-2\%). The reduction in milk yield also depends on the breed and age of the cows. A study by Litwińczuk et al. (2011) showed that as SCC increased, daily milk yield in cows successively decreased. The greatest difference in daily milk yield between group 4 (over 500,000/ml SCC) and group 1 (up to $100,000 / \mathrm{ml} \mathrm{SCC}$ ) was noted in the Polish Holstein-Friesians (about 25\%), and the lowest in the Jersey cows (about $13 \%$ ). Schroeder (2012) reports that losses in milk production are nearly twice as high in older cows as in cows in their first lactation. Similar results were obtained by Halasa et al. (2009), who analysed productivity losses in 39,512 cows kept in 400 herds in the Netherlands. Where the somatic cell count was $200,000 / \mathrm{ml}$, primiparous cows produced $0.31 \mathrm{~kg}$ less milk, while the decrease in multiparous cows was $0.58 \mathrm{~kg}$.

Mastitis also negatively affects reproductive indicators in dairy cows, including day of first service, conception rate, and in consequence, the calving-to-conception interval (Gunay and Gunay, 2008). Barker et al. (1998) found that mastitis occurring during early lactation significantly affected the reproduction capacity of Jersey cows. They determined that cows with subclinical mastitis were first inseminated substantially later (day $93.6 \pm 5.6$ of lactation) than healthy cows (day 71.0 \pm 2.2 ). However, they found no correlation between reproductive indicators and the type of pathogen inducing the mastitis. Yang et al. (2012) report that in cows with diagnosed mastitis the first service after parturition was performed on average on day 73.84, which was nearly 20 days later than in healthy cows (day 54.73). Moreover, they found that cows with mastitis conceived on average after 1.88 procedures, with a conception rate of $38 \%$, in comparison with healthy cows, in which the corresponding indicators were $1.53 \%$ and $54.9 \%$. Cows with newly diagnosed mastitis, i.e. when it did not occur until after the first service, conceived on average after 2.19 procedures, with a conception rate of only $27.8 \%$. Nava-Trujillo et al. (2010) observed that in cows with clinical mastitis the first service was performed on average on day 136.31 of lactation, compared to day 98.53 in healthy cows. This had a decisive influence on the length of the calving-to-conception interval, which was 187.21 and 143.95 days, respectively, the number of services -2.35 and 2.21 , and the conception rate after the first service $-49.72 \%$ and $56.10 \%$. Negative correlations between mastitis during early lactation in cows were also obtained by Gunay and Gunay (2008). McDougall et al. (2005) pointed out the greater risk of loss of pregnancy (1.57 times higher) in 
cows in which mastitis occurred during this period in comparison with cows with no inflammation.

It is estimated that milk producers in Poland lose over 5 million PLN annually due to mastitis, which is associated with a reduction in milk production of about $20 \%$. In the case of clinical mastitis, the total cost is estimated at about $200 € /$ cow, but this value is variable (Heikkilä et al., 2012; Steeneveld et al., 2011). In Finland the average cost of treating clinical mastitis in Ayrshire cows was $485 € / \mathrm{cow}$ (from 112 to $1,006 € / \mathrm{cow}$ ), and $458 €$ in Holstein-Friesian cows (209 to $946 € / \mathrm{cow}$ ) (Heikkilä et al., 2012). In an American study (Steeneveld et al., 2011), the average cost of treating clinical mastitis was estimated at $252 \mathrm{USD} / \mathrm{cow}$. Losses incurred due to subclinical mastitis are even greater. This is mainly due to the long-term decrease in milk production, as many cows produce considerably less milk than their potential. It is worth mentioning that mastitis causes reduced milk production not only during the inflammation, but in the remainder of the lactation period as well (Hagnestam et al., 2007).

To sum up, systematic monitoring of the health condition of the udder is currently the most important problem for dairy cow farmers. Resistance, or rather susceptibility of cows to mastitis has a genetic basis, so researchers are seeking genetic markers determining this trait. Apart from the etiological agent, factors associated with farming practice are significant as well, such as the breed and age of the cows and the stage of lactation, particularly the dry period. Opinions differ regarding the effect of automatic milking systems on the health condition of the udder.

\section{References}

A b r a h m s é n M., P e r s s o n Y., K a n y i m a B.M., B å g e R. (2014). Prevalence of subclinical mastitis in dairy farms in urban and peri-urban areas of Kampala, Uganda. Trop. Anim. Health Prod., 46: 99-105.

Arnould V.M., Soyeurt H., Gengler N., Colinet F.G., Georges M.V., B ertozzi C., Portetelle D., Renaville R. (2009). Genetic analysis of lactoferrin content in bovine milk. J. Dairy Sci., 92: 2151-2158.

A shwell M.S., Heyen D.W., Sonstegard T.S., Van Tassel C.P., Da Y., Van Rad e n P.M., R o n M., We 11 e r J.I., L e w i n H.A. (2004). Detection of quantitative trait loci affecting milk production, health, and reproduction traits in Holstein cattle. J. Dairy Sci., 87: 468-475.

Aw a le M.M., Dudhatra G.B., Avin ash K., Chauhan B.N., Ka man i D.R., Modi C.M., P a te l H.B., Mody S.K. (2012). Bovine mastitis: A threat to economy. Open Access Scientific Reports, 1: 295, doi:104172/scientificreports.295.

B arker A.R., S chrick F.N., L ew is M.J., D ow len H.H., Olive r S.P. (1998). Influence of clinical mastitis during early lactation on reproductive performance of Jersey cows. J. Dairy Sci., 81: $1285-1290$.

B arłowska J., Litwińczuk Z., Wolanciuk A., Brodziak A. (2009). Relationship of somatic cell count to daily yield and technological usefulness of milk from different breeds of cows. Polish J. Vet. Sci., 12: 75-79.

B e rry D.P., M e a n e y W.J. (2005). Cow factors affecting the risk of clinical mastitis. Irish J. Agr. Food Res., 44: 147-156.

B loemhof S., de Jong G., de Haas Y. (2009). Genetic parameters for clinical mastitis in the first three lactations of Dutch Holstein cattle. Vet. Microbiol., 134: 165-171. 
B orkowska A., Litwiń c zuk Z. (1989). Analysis of changes in body composition and capacity indicators in the first three lactations of Black and White cows and $\mathrm{cb} \times \mathrm{hf}$ crossbreeds (in Polish). Ann. UMCS, s. EE, VII: 11-20.

B or m A.A., F ox L.K., L e s 1 i e K.E., H o g a n J.S., A n d rew S.M., M o y e s K.M., Oliver S.P., Schukkun Y.H., Hanncock D.D., Gaskins C.T., Owens W.E., Norman C. (2006). Effect of prepartum intramammary antibiotic therapy on udder health, milk production, and reproductive performance in dairy heifers. J. Dairy Sci., 89: 2090-2098.

Carlen E., Strandberg E., Roth A. (2004). Genetic parameters for clinical mastitis, somatic cell score, and production in the first three lactations of Swedish Holstein cows. J. Dairy Sci., 87: 3062-3070.

C o m p t on C.W.R., H e u r e r C., P a r k e r K., M c D o u g a 11 S. (2007). Risk factors for peripartum mastitis in pasture-grazed heifers. J. Dairy Sci., 90: 4171-4180.

Dohmen W., Neijenhuis F., Hogeveen H. (2009). Relationship between udder health and hygiene on farms with an automatic milking system. J. Dairy Sci., 93: 4019-4033.

D u b e B., D z a m a K., B an g a C.B. (2008). Genetic analysis of somatic cell score and udder type traits in South African Holstein cows. S. Afr. J. Anim. Sci., 38: 1-11.

E 1 b a bly M.A., E m e a s h H.H., A s m a a N.M. (2013). Risk factors associated with mastitis occurrence in dairy herds in Benisuef, Egypt. World's Vet. J., 3: 5-10.

Gołę b i ew s k i M., B r z o z ow s k i P. (2007). Montbeliarde-economical breed of cattle (in Polish). Prz. Hod., 2: 7-9.

Guliński P., Litw ińczuk Z., Młynek K., Tumiłowicz A. (1996). Research on the relationship between the outer structure of udders in cows and their susceptibility to the occurrence of mastitis (in Polish). Part I-II. Ann. UMCS, s. EE, XIV: 43-53.

Gunay A., Gunay U. (2008). Effects of clinical mastitis on reproductive performance in Holstein cows. Acta Vet. (Brno), 77: 555-560.

H a g n e st a m C., Em a n u e l s on U., B e rg l und B. (2007). Yield losses associated with clinical mastitis occurring in different weeks of lactation. J. Dairy Sci., 90: 2260-2270.

Ha la s a T., N i e len M., D e R o os APW., Van Hoorne R., d e Jong G., La m T.J.G.M., van Werven T., Hogeve en H. (2009). Production loss due to new subclinical mastitis in Dutch dairy cows estimated with a test-day model. J. Dairy Sci., 92: 599-606.

Harouna A., Zecchini M., Locatelli C., Scaccabarozzi L., Cattaneo C., A madou A., Bronzo V., Marichatou H., Boettcher P.J., Zanoni M.G., Alborali L., Mor o n i P. (2009). Milk hygiene and udder health in the periurban area of Hamidallaye, Niger. Trop. Anim. Health Prod., 41: 705-710.

He ikkilä A.M., Nous ia in en J.I., P y örälä S. (2012). Costs of clinical mastitis with special reference to premature culling. J. Dairy Sci., 95: 139-150.

H o g e v e e n H. (2005). Mastitis in dairy production: current knowledge and future solutions. Wageningen Academic Publishers, The Netherlands.

Hovinen M., R a s mus s en M.D., P y örälä S. (2009). Udder health of cows changing from tie stalls or free stalls with conventional milking to free stalls with either conventional or automatic milking. J. Dairy Sci., 92: 3696-3703.

H u ijps K., L a m T.J.G.M., H o g e v e e n H. (2008). Costs of mastitis: facts and perception. J. Dairy Res., 75: 113-120.

Hus s a in R., K han A., J a ve d M.T., R i zv i F. (2012). Possible risk factors associated with mastitis in indigenous cattle in Punjab, Pakistan. Pak. Vet. J., 32: 605-608.

J o n e s G.M., B a i l e y T.L. (2009). Understanding the basics of mastitis. Virginia Cooperative Extension, Publication 404-233. Virginia Tech, USA, pp. 1-5.

Ka miński S., O leńs ki K., B ry m P., Ma lew ski T., S a zanov A.A. (2006). Single nucleotide polymorphism in the promotor region of the lactoferrin gene and its associations with milk performance traits in Polish Holstein cows. Russ. J. Genet., 42: 924-927.

K h a n M.Z., K ha n A. (2006). Basic facts of mastitis in dairy animals: A review. Pakistan Vet. J., 26: 204-208.

K ról J., Litw iń c zu k Z., B rodzi a k A., B arło w s k a J. (2010). Lactoferrin, lysozyme and immunoglobulin $\mathrm{G}$ content in milk of four breeds of cows managed under intensive production system. Polish J. Vet. Sci., 13: 357-361. 
Król J., Brodziak A., Litwińczuk Z., Litwińczuk A. (2013). Effect of age and stage of lactation on whey protein content in milk of cows of different breeds. Polish J. Vet. Sci., 16: 395-397.

Kuhn M.T., Hutch is on J.L., N or m a n H.D. (2007). Dry period length in US Jersey: Characterization and effect on performance. J. Dairy Sci., 90: 2069-2081.

L a v e n R.A., B a l c o m b C.C., Tu 11 e y W.T., L a w r e n c e K.E. (2014). Effect of dry period length on the effect of an intramammary teat sealant on the risk of mastitis in cattle treated with antibiotics at drying off. New Zeal. Vet. J., 62: 214-220.

Len ts C.A., We t te mann R.P., P a a p e M.J., L o o per M.L., B u chan an D.S. (2008). Effects of dry cow treatment of beef cows on pathogenic organisms, milk somatic cell counts, and calf growth during the subsequent lactation. J. Anim. Sci., 86: 748-755.

Litwińczuk Z., A s a rabowska A., Borkowska D., Gnyp J. (1990). Udder structure and milking ability of $\mathrm{cb}$ ' hf heifers maintained in a various environmental conditions (in Polish). Rocz. Nauk Roln., 106: 61-75.

Litwińczuk Z., Król J., Brodziak A., B arłowska J. (2011). Changes of protein content and its fractions in bovine milk from different cow breeds subject to somatic cell count. J. Dairy Sci., 94: 684-691.

Madou as e A., Browne W.J., Huxley J.N., Toni F., Bradley A.J., Green M.J. (2012). Risk factors for a high somatic cell count at the first milk recording in a large sample of UK dairy herds. J. Dairy Sci., 95: 1873-1884.

Malinow ski E., S muls ki S. (2007). Occurrence and prevention of infections and inflammations of mammary gland in heifers (in Polish). Życie Wet., 82: 476-482.

M c D o u ga 11 S., P a r ke r K., C o m p t o n C., H e u e r C. (2005). Reducing subclinical and clinical mastitis in dairy heifers by precalving infusion of a teat sealant and/or parenteral antibiotic therapy. Proc. 4th Intl. Dairy Fed. Intl. Mastitis Conf. Maastricht, The Netherlands, pp. 269-273.

Mrode R.A., Sw an s on G.J.T. (1996). Genetic and statistical properties of somatic cell count and its suitability as an indirect means of reducing the incidence of mastitis in dairy cattle. Anim. Breed. Abstr., 164: 847-857.

Nava-Trujillo H., Soto-Bellos o E., Hoet A.E. (2010). Effects of clinical mastitis from calving to first service on reproductive performance in dual-purpose cows. Anim. Reprod. Sci., 121: $12-16$.

Norberg E., M a d s e n P., P e derse n J. (2009). A multi-trait genetic analysis of protein yield, udder health, and fertility in first lactation Danish Holstein, Danish Red and Danish Jersey using an animal model. Acta Agr. Scand. A: Anim. Sci., 59: 197-203.

Ogorevc J., Kunej T., Razpet A., Dovc P. (2009). Database of cattle candidate genes and genetic markers for milk production and mastitis. Anim. Genet., 40: 832-851.

O l e c hnow i c z J., J ás k ow s k i J.M. (2012). Somatic cells count in cow's bulk tank milk. J. Vet. Med. Sci., 74: 681-686.

Oviedo-Boyso J., Valdez-A larcon J.J., Cajero-Juárez M., Ochoa-Zarzosa A., Ló pe z-M e za J.E., B ravo-P atiño A., B a i zaba l-A guirre V.M. (2007). Innate immune response of bovine mammary gland to pathogenic bacteria responsible for mastitis. J. Infectol., 54: 399-409.

Paape M.J., Duenas M.I., We t te mann R.P., D ouglas s L.W. (2000). Effects of intramammary infection on parity on calf weaning weight and milk quality in beef cows. J. Anim. Sci., 78: 2508-2514.

Parker K.I., Compton C., Annis s F.M., We ir A., Heuer C., McDougall S. (2007). Subclinical and clinical mastitis in heifers following the use of a teat sealant precalving. J. Dairy Sci., 90: 207-218.

Pashmi M., Q anbari S., Ghorashi S.A., Sharifi A.R. (2009). Analysis of relationship between bovine lymphocyte antigen DRB3.2 alleles, somatic cell count and milk traits in Iranian Holstein population. J. Anim. Breed. Genet., 126: 296-303.

Pawlik A., Sender G., Sobczyńska M., Korwin-Kossakowska A., Oprządek J., Ł u k a s z e w i c z M. (2014). Association between lactoferrin single nucleotide polymorphisms and milk production traits in Polish Holstein cattle. Arch. Tierzucht., 57: 1-12.

Penas a M., Cecchinato A., Battagin M., De Marchi M., Pretto D., Cas sandro M. 
(2010). Bayesian inference of genetic parameters for test-day milk yield, milk quality traits, and somatic cell score in Burlina cows. J. Appl. Genet., 51: 489-495.

Ptak E., Jagusiak W., Żarnecki A., Otwinowska-Mindur A. (2009). Genetic parameters of daily somatic cell score and some conformation traits in Polish Holstein cattle. Ann. Anim. Sci., 9: 355-361.

P y ör älä S. (2003). Indicators of inflammation in the diagnosis of mastitis. Vet. Res., 34: 565-568.

Rupp R., B oichard D. (2003). Genetics of resistance to mastitis in dairy cattle. Vet. Res., 34: $671-688$.

Rzew usk a K., Ja mrozik J., Ż ar ne cki A., S trabel T. (2011). Genetic parameters of test-day somatic cell scores for the first three lactations of Polish Holstein-Friesian cattle. Czech J. Anim. Sci., 56: 381-389.

S a la mończyk E., Guliński P. (2013). Somatic cell level in dairy cow's milk during extended lactation. Ann. Anim. Sci., 13: 859-868.

S aw a A., Kręże l-Czopek S., B o gucki M. (2015). Dry period length as related to milk yield and SCC during the first month of subsequent lactation. Ann. Anim. Sci., 15: 155-163.

Schroeder J.W. (2012). Bovine mastitis and milking management. Mastitis Control Programs. NDSU Extension Service, North Dakota State University Fargo, North Dakota, AS1129: 1-16.

S e n d e r G. (2001). Resistance to mastitis as a component of a breeding goal in dairy cattle improving programmes (in Polish). Pr. Mat. Zoot., Special Issue, 12: 1-61.

S ender G., Korwin-Kossakowska A., Galal Abdel Hameid K., Prusak B. (2006). Association of the polymorphism of some genes with the occurrence of mastitis in cattle (in Polish). Med. Weter., 65: 563-565.

$\mathrm{S}$ h a r if S., M a 11 ard B.A., S a r g e a n t J.M. (2000). Presence of glutamine at position 74 of pocket 4 in the BoLA-DR antigen binding groove is associated with occurrence of clinical mastitis caused by Staphylococcus species. Vet. Immunol. Immunop., 76: 231-238.

$\mathrm{S}$ h a r m a N., M a it i S.K. (2005). Effect of dietary supplementation of vitamin $\mathrm{E}$ and selenium in sub clinical mastitis in dairy cows. Indian J. Vet. Med., 25: 76.

Shittu A., Abdullahi J., Jibril A., Mohammed A.A., Fas ina F.O. (2012). Subclinical mastitis and associated risk factors on lactating cows in the Savannah Region of Nigeria. BMC Vet. Res., 8: 134-141.

S m ith K.L., H o g a n J.S., We is s W.P. (1997). Dietary vitamin E and selenium affect mastitis and milk quality. J. Anim. Sci., 75: 1659-1665.

S m ith J.W., E 1y L.O., G rave s W.M., Gil s on W.D. (2002). Effect of milking frequency on DHI performance measures. J. Dairy Sci., 85: 3526-3533.

S teeneveld W., van Werven T., B arkema H.W., Hogeveen H. (2011). Cow-specific treatment of clinical mastitis: an economic approach. J. Dairy Sci., 94: 174-188.

S udh an N.A., Sharma N. (2010). Mastitis - an important production disease of dairy animals. SMVS' Dairy Year Book, 1st Ed., Published by Sarva Manav Vikash Samiti, Gurgoan, India, pp. $72-88$.

Tiwari J.G., B abra C., Tiwar i H.K., Willi a m s V., de Wet S., Gibson J., Pax man A., Morgan E., Costantino P., Sunagar R., Isloor S., Mukkur T. (2013). Trends in therapeutic and prevention strategies for management of bovine mastitis: An overview. J. Vaccines Vaccination, 4: 1-11.

Van den Borne B.H., van Schaik G., Lam T.J., Nielen M. (2010). Variation in herd level mastitis indicators between primi- and multiparae in Dutch dairy herds. Prev. Vet. Med., 96: $49-55$.

Voorst Y.H. van der, Hogeveen H. (2000). Automatic milking systems and milk quality in The Netherlands, Proc. International Symposium Robotic Milking, Lelystad, The Netherlands, 17-19.08.2000, pp. 73-82.

Wa 11 e r K.P., P er s s o n Y., N y m a n A.K., S t e $n$ g är d e L. (2014). Udder health in beef cows and its association with calf growth. Acta Vet. Scand., 56: 1-8.

Walsh R.B., K el t o n D.F., D u ff i e ld T.F., L e s l i e K.E., Wal t on J.S., L e B 1 a n c S.J. (2007). Prevalence and risk factors for postpartum anovulatory condition in dairy cows. J. Dairy Sci., 90: 315-324.

W ę g l a r z y K. (2009). Effect of dry period length on dairy cows production level (in Polish). Pr. Mat. Zoot., 67: 218. 
Woj dak-M k k y mi e c K., K mi é M., Zi e mak J. (2006). Associations between bovine lactoferrin gene polymorphism and somatic cell count in milk. Med. Weter., 51: 14-20.

Wojdak-Maksymiec K., Kmieć M., Kowalewska-Luczak I., Warliński M. (2010). DRB3 Gene polymorphism and somatic cell count in milk of Jersey cows. J. Anim. Vet. Adv., 9: 1295-1300.

Yang F.L., Li X.S., Yang B.Z., Zhang Y., Zhang X.F., Q in G.S., L i ang X.W. (2012). Clinical mastitis from calving to next conception negatively affected reproductive performance of dairy cows in Nanning, China. Afr. J. Biotechnol., 11: 2574-2580.

Zabolewicz T., Brym P., Oleński K., Suchocki T., Malewski T., Szyda J., K a m iń s k i S. (2012). Polymorphism within TATAbox of bovine lactoferrin gene and its association with performance traits in Holstein cattle. Livest. Sci., 149: 267-274.

Zecconi A., Pic cini R., Casirani G., Binda E., Migliorati L. (2003). Effects of automatic milking system on teat tissues, intramammary infections and somatic cell count. Ital. J. Anim. Sci., 2: 275-282.

Received: 29 I 2015

Accepted: 13 V 2015 